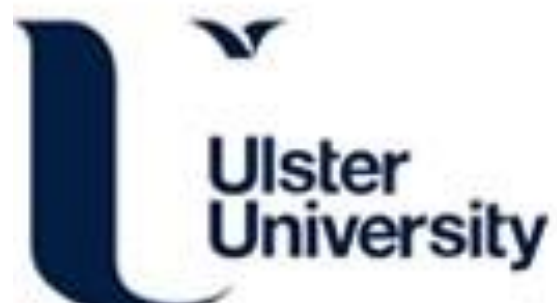

\section{Supporting content and language integrated learning through technology}

Gimeno-Sanz, A., Ó Dónaill, C., \& Andersen, K. (2014). Supporting content and language integrated learning through technology. In CALL Design: Principles and Practice - Proceedings of the 2014 EUROCALL Conference, Groningen, The Netherlands (pp. 107-112). Research Publishing. https://doi.org/10.14705/rpnet.2014.000203

Link to publication record in Ulster University Research Portal

\section{Published in:}

CALL Design: Principles and Practice - Proceedings of the 2014 EUROCALL Conference, Groningen, The Netherlands

\section{Publication Status:}

Published (in print/issue): 14/12/2014

DOI:

https://doi.org/10.14705/rpnet.2014.000203

\section{Document Version}

Publisher's PDF, also known as Version of record

\section{General rights}

Copyright for the publications made accessible via Ulster University's Research Portal is retained by the author(s) and / or other copyright owners and it is a condition of accessing these publications that users recognise and abide by the legal requirements associated with these rights.

\section{Take down policy}

The Research Portal is Ulster University's institutional repository that provides access to Ulster's research outputs. Every effort has been made to ensure that content in the Research Portal does not infringe any person's rights, or applicable UK laws. If you discover content in the Research Portal that you believe breaches copyright or violates any law, please contact pure-support@ulster.ac.uk. 


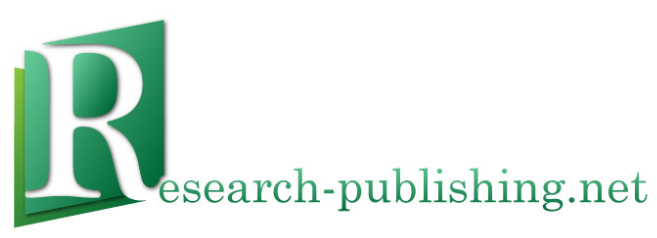

Published by Research-publishing.net, not-for-profit association Dublin, Ireland; Voillans, France, info@research-publishing.net

(C) 2014 by Research-publishing.net

Each author retains their own copyright

CALL Design: Principles and Practice

Proceedings of the 2014 EUROCALL Conference, Groningen, The Netherlands

Edited by Sake Jager, Linda Bradley, Estelle J. Meima, and Sylvie Thouësny

Rights: All articles in this collection are published under the Attribution-NonCommercial -NoDerivatives 4.0 International (CC BY-NC-ND 4.0) licence. Under this licence, the contents are freely available online (as PDF files) for anybody to read, download, copy, and redistribute provided that the author(s), editorial team, and publisher are properly cited. Commercial use and derivative works are, however, not permitted.

\section{(@) $\mathbb{Q} \Theta$}

Disclaimer: Research-publishing.net does not take any responsibility for the content of the pages written by the authors of this book. The authors have recognised that the work described was not published before, or that it is not under consideration for publication elsewhere. While the information in this book are believed to be true and accurate on the date of its going to press, neither the editorial team, nor the publisher can accept any legal responsibility for any errors or omissions that may be made. The publisher makes no warranty, expressed or implied, with respect to the material contained herein. While Research-publishing.net is committed to publishing works of integrity, the words are the authors' alone.

Trademark notice: product or corporate names may be trademarks or registered trademarks, and are used only for identification and explanation without intent to infringe.

Copyrighted material: every effort has been made by the editorial team to trace copyright holders and to obtain their permission for the use of copyrighted material in this book. In the event of errors or omissions, please notify the publisher of any corrections that will need to be incorporated in future editions of this book.

Typeset by Research-publishing.net

Cover design: (C) Raphaël Savina (raphael@savina.net)

Fonts used are licensed under a SIL Open Font License

ISBN13: 978-1-908416-19-3 (Paperback - Print on demand, black and white)

Print on demand technology is a high-quality, innovative and ecological printing method; with which the book is never 'out of stock' or 'out of print'.

ISBN13: 978-1-908416-20-9 (Ebook, PDF, colour)

ISBN13: 978-1-908416-21-6(Ebook, EPUB, colour)

Legal deposit, Ireland: The National Library of Ireland, The Library of Trinity College, The Library of the University of Limerick, The Library of Dublin City University, The Library of NUI Cork, The Library of NUI Maynooth, The Library of University College Dublin, The Library of NUI Galway.

Legal deposit, United Kingdom: The British Library.

British Library Cataloguing-in-Publication Data.

A cataloguing record for this book is available from the British Library.

Legal deposit, France: Bibliothèque Nationale de France - Dépôt légal: décembre 2014. 


\title{
Supporting content and language integrated learning through technology
}

\author{
Ana Gimeno-Sanz ${ }^{1}$, Caoimhín Ó Dónaill², and Kent Andersen ${ }^{3}$
}

\begin{abstract}
This paper describes Clilstore and how this tool can support Content and Language Integrated Learning (CLIL), which involves teaching a curricular subject through the medium of a foreign language, as was evidenced through data collected from two surveys conducted with secondary school teachers from various European countries.
\end{abstract}

Keywords: content and language integrated learning, Clilstore, tools for CLIL teachers project.

\section{Introduction}

Content and Language Integrated Learning was recognised as a teaching methodology by the Commission of the European Communities in its Communication No. 449 on Promoting Language Learning and Linguistic Diversity: An Action Plan 2004-2006, published in 2003. In this past decade we have witnessed how CLIL has steadily rooted its teaching principles and is slowly becoming a dominant methodology in all sectors of education that are sensitive to bilingual education. Research and reflective practice literature is currently abundant and CLIL is the focus of an increasing amount of empirical studies proving the methodology's worth. In line with this trend, the EU-funded Tools for CLIL Teachers project has developed an online authoring tool to support the implementation of CLIL. This tool, which is known as Clilstore, facilitates being able to automatically link every word in a text to freely available online dictionaries

1. Universidad Politécnica de Valencia, Spain; agimeno@upvnet.upv.es.

2. University of Ulster, Northern Ireland, UK; c.odonaill@ulster.ac.uk.

3. Syddansk Erhvervsskole Odense, Denmark; ka@sde.dk.

How to cite this article: Gimeno-Sanz, A., Ó Dónaill, C., \& Andersen, K. (2014). Supporting content and language integrated learning through technology. In S. Jager, L. Bradley, E. J. Meima, \& S. Thouësny (Eds), CALL Design: Principles and Practice; Proceedings of the 2014 EUROCALL Conference, Groningen, The Netherlands (pp. 107-112). Dublin: Research-publishing.net. doi:10.14705/rpnet.2014.000203 
in a wealth of languages. Clilstore's features are particularly enhanced when videos and their transcripts are embedded into the system from one of the many streaming video applications currently available. The units created within Clilstore become part of an ever-growing repository for learners and teachers alike.

\section{Methodology}

\subsection{Content and language integrated learning}

The EU's policy on multilingualism mentioned above states that CLIL implicates teaching a curricular subject through the medium of a language other than that normally used. The subject can be entirely unrelated to language learning, delivered in a bilingual context, or include a language learning component serving a dual purpose: that of the subject matter and that of a foreign language. CLIL has steadily been on the rise for the past 20 years and this trend is continuing, judging by the amount of literature currently available.

Teachers who adopt the CLIL methodology are specialists in a discipline other than the foreign language. They are by definition proficient speakers of the target language and very often collaborate with language teachers. The crucial factor here is that the learners acquire new knowledge with regard to the subject matter whilst simultaneously practising and acquiring the foreign language. However, it is commonly the content of the curricular subject that determines the types of activities used and the methodologies and teaching approaches to be followed.

\subsection{Clilstore, Multidict and Wordlink}

Clilstore is a simple-to-use, yet extremely powerful, authoring tool that enables teachers to create materials based on the integration of streaming video embedded from external sources, together with a repository of ready-made materials for teachers and learners alike. The materials currently available in Clilstore amount to 1,133 units, covering all 6 levels (A1 to C2) of the Common European Framework of Reference for Languages in 47 different languages.

Clilstore is built on two interconnected tools, that is, Multidict and Wordlink. Both tools can function as stand-alone resources or within Clilstore. Multidict is a dictionary interface allowing quick monolingual or bilingual searches in over 100 language combinations. Wordlink is the software interface that can connect most webpages, word by word, to existing free online dictionaries. It allows users to automatically link any of the words that appear within a text included in a Clilstore 
unit to a vast selection of dictionaries, thereby supporting learners when reading online as immediate dictionary consultation is guaranteed.

In Figure 1 we can see the typical layout of a Clilstore unit. The unit belongs to the repository of units for learners of Spanish at a B2 level of proficiency and includes the entire script of a YouTube video describing the features and uses of graphene. The use of Wordlink has automatically associated all of the words in the script to Multidict, thereby linking them to all the available online monolingual and bilingual dictionaries. As we can see in the illustration below, the word "tejidos" (tissues) has been selected; this triggers the Multidict dictionary interface to appear on the right hand side of the screen (default mode). The parameters of the word being looked up can be pictured below: 1) the source language, 2) the target language for translation, and 3 ) the selected online dictionary. It is not necessary to re-enter the search term in order to switch between dictionaries (Gimeno, Ó Dónaill, \& Zygmantaite, 2013).

Figure 1. Sample Clilstore unit

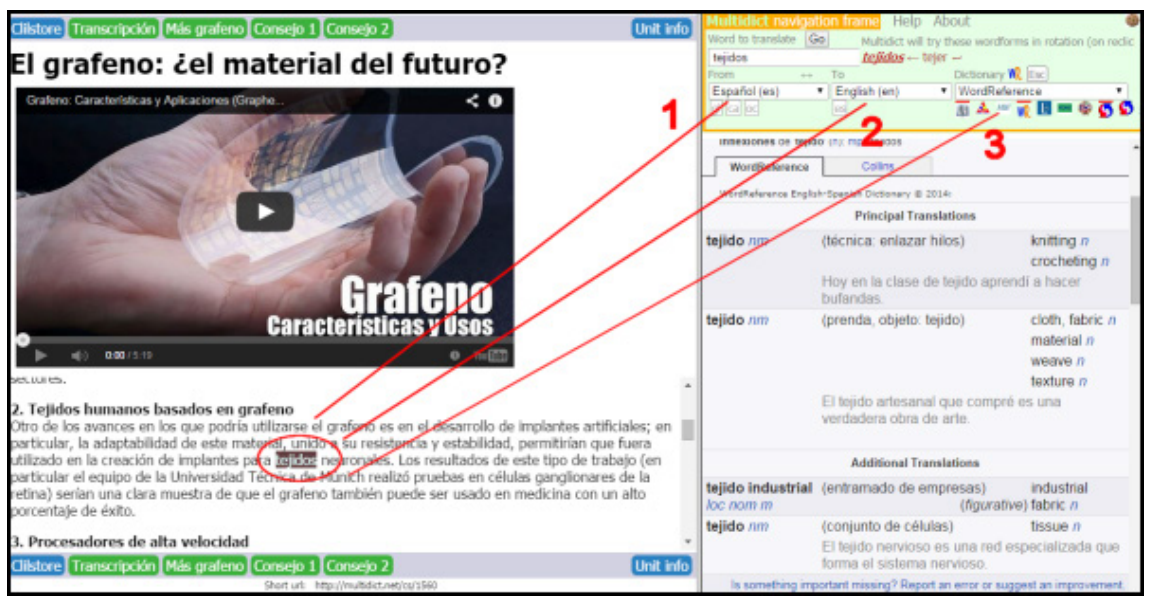

\section{Discussion}

In order to validate Clilstore and its integral modules, Multidict and Wordlink, and to determine a) to which extent training courses focusing on the use of Clilstore can become helpful to develop CLIL skills and b) to which extent Clilstore was helpful in achieving this, three members of the Tools for CLIL Teachers project participated in a European-wide teacher training course and conducted a survey based on precourse and post-course opinion questionnaires. In the initial questionnaire, the 
questions were geared towards discovering the participant's prior knowledge about CLIL, their readiness to adopt such a methodology and their attitude towards using ICT in their teaching practice. This survey unveiled a general lack of awareness regarding the theories underlying CLIL and the practicalities involved in adopting this methodology; lack of knowledge as to ICT resources that are available to support the teacher and a tendency to use practices firmly grounded on a teachercentred approach. The final survey intended to collect data regarding their level of confidence in applying a number of CLIL attributes in their teaching, the degree to which they thought CLIL relies on ICT, and their perception of learner versus teacher-centred approaches, after having completed the two-week course.

The participants consisted of 30 secondary school teachers from nine different European countries teaching subjects ranging from Electronics, Telecommunications, Computing and ICT to Geography, History, Science, Music and Art. They all held certificates accrediting a B2 level or higher of English proficiency.

Regarding their opinion of the CLIL concept in general after completing the course, the entire class was favourable to applying this methodology in their teaching. The following are a few comments that we think are worth mentioning because they summarise the overall impression:

- “The CLIL methodology is useful to improve the students' motivation in learning because it involves the use of different means of communication and it integrates a wide variety of pedagogical methodologies. The lessons built in this way are more interesting for students".

- "[CLIL] is a new methodology based on multimodality and scaffolding, which is very useful".

- "In my opinion CLIL is a good method to transfer content and language, even if you have to create all your lessons and it is a big job".

- "I think CLIL is a very ambitious concept. If it works, it is perfect for the students but I think it takes a lot of time for CLIL to work with students, and it takes a lot of time for teachers to prepare lessons".

From these comments we can elicit several conclusions that were, in general, common to the whole group: a) teachers perceive CLIL as a means of motivation for students because it involves using multiple approaches to teaching, b) it assimilates 
multimodality in learning, and c) it caters for a variety of learning styles. As can be seen, the main drawback is related to the amount of extra work and time that has to be invested in preparing suitable lessons in order to adapt their subject matter to the CLIL methodology.

Regarding the degree of confidence in applying CLIL after taking the course, $48.15 \%$ state that they are confident and $18.58 \%$ state that they are very confident in developing learning outcomes for both language and subject matter. If we consider the sum of these two statements, over $65 \%$ of the participants perceive CLIL as an optimal methodology to teach both content and language. The participants' confidence to provide multimodal input and distributing it evenly across their CLIL units increased to levels of very confident (48.15\%) and confident (40.74\%), adding up to nearly $90 \%$. Self-confidence in being able to incline the balance towards student-centred learning rather than teacher-centred learning was another of the attributes where the course had helped participants gain assertiveness: very confident $(33.33 \%)$ and confident (51.85\%), adding up to a total of $85 \%$ of the participants. Additionally, $77.8 \%$ of the respondents claimed that the introductory course on CLIL and the use of Clilstore had changed their views on teacher-centred versus learner-centred learning and provided the following explanations:

- "Students should be more involved in their learning".

- "Yes, I will try to apply more student-oriented education".

- "In Italy the widespread methodology is teacher-centred; so I have learnt different ways of teaching and, in the end, a dramatic change in the way of thinking and planning lessons".

- "The tools that I have learnt are very interesting, but it is necessary [to] employ a lot of time to build the lesson, because in my case there are very few existing materials. And it is a huge effort to create the material in English".

- "Using these tools changed my views on learning-centered approaches".

As we can see, in a number of cases, the course encouraged teachers to change their focus from teaching to learning and their will to incorporate methods to support the learner and increase their involvement in the process, despite the amount of work that creating ad-hoc materials may imply in areas where there are less ready-made resources available. 
Regarding how reliant CLIL is on ICT, again the views of the respondents coincided considerably. $29.63 \%$ stated that CLIL relied very strongly and $55.56 \%$, strongly, adding up to over $85 \%$ of the group. $11.11 \%$ were neutral and $3.70 \%$ disagreed entirely and thought that CLIL could be put into practice independently of ICT. One of the respondents commented that CLIL "is not necessarily reliant [on ICT]. There are lots of things that can be done without it, especially Wordlink as it just helps to understand a text, it doesn't teach understanding skills".

When asked about the usefulness of the Clilstore system to design units for CLIL in their own subject, nearly $85 \%$ of the respondents rated it as high or very high.

One of the general remarks -which can be summarised in the following opinion: "It is necessary to have a global planning to state the main principles and practice[s] of CLIL in Europe. It is not a good idea that each teacher uses CLIL as they consider the best way"- points, in our opinion, to one of the key factors that can cause teachers to hesitate putting CLIL into practice, i.e. the fact that subject specialists need well-developed methodological guidelines to support the implementation of CLIL in the classroom and the backing of language specialists to provide support in terms of foreign language learning.

\section{Conclusions}

Evidence drawn from the post teacher training course questionnaire leads us to believe that a) teachers are willing to adopt CLIL in their classes and to collaborate with language specialists to put this dual-focus methodology into practice, and b) Clilstore is perceived as a useful tool in order to create, publish and deliver learning materials that aid in conducting dual-focused teaching by supporting content learning as well as foreign language learning.

\section{Reference}

Gimeno, A., Ó Dónaill, C., \& Zygmantaite, R. (2013). Clilstore Guidebook for Teachers. Retrieved from http://www.languages.dk/archive/tools/guides/ClilstoreGuidebook.pdf 